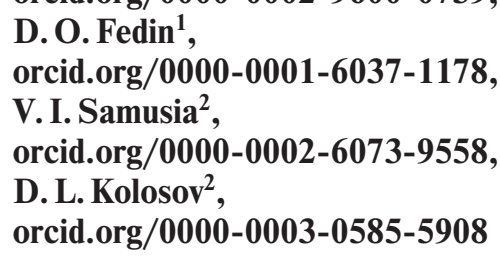

\author{
1 - University of Chemical Technology, Dnipro, Ukraine, \\ e-mail: borvvin@gmail.com \\ 2 - Dnipro University of Technology, Dnipro, Ukraine
}

\title{
DYNAMIC LOADS IN SELF-ALIGNING GEAR TRANSMISSIONS OF HEAVY LOADED MACHINES
}

Purpose. Development of a mathematical model of a heavy loaded gear transmission with a self-aligning drive gear; evaluation of the dynamic load on the gear transmission in the gear alignment process.

Methodology. The calculation schematic and equations of the relative motion of the self-aligning drive gear are formed using the methods of rigid body dynamics. Analytical expressions for the gear self-alignment time, collision velocity during the alignment and dynamic load factor are obtained by integrating an ordinary differential equation. Methods of the linear theory for oscillations are used to determine the dynamic factor.

Findings. The article investigates the state-of-art design and mathematical models of the self-aligning gear. An equation for the relative motion of the moving part of the gear has been formed using the methods of rigid body dynamics. It is shown that by using the proposed hypotheses, the movement of the gear can be reduced to rotation about the instantaneous axis. The influence of geometric and dynamic parameters of the ball mill drive on dynamic loads in the open gear transmission is investigated. The gear alignment speed dependences on the tooth mesh misalignment angle in the gear transmission and the inertial parameters of the gear have been obtained. The obtained dependencies were used to calculate the time and speed of the gear alignment in the open gear transmission of the ball mill МШЦ $5.5 \times 6.5$ (central discharge ball mill). It is shown that in the real range of mesh misalignment angles and gear parameters, the time of the gear alignment is several orders of magnitude less than the time of teeth re-engagement. In the presence of the variable component of the mesh misalignment angle, the gear will constantly make a relative motion with strikes; depending on the current value of the mesh misalignment angle, the dynamic load on the gear transmission can be significant. It is shown that when assessing the efficacy of self-aligning gears, it is necessary to take into account a possible increase in dynamic loads. The dynamic factor and the load factor are calculated for the nominal value of the mesh misalignment angle in the open gear transmission of МШЦ $5.5 \times 6.5$ ball mills.

Originality. A mathematical model of the dynamics of a self-aligning gear transmission in heavy duty machine drives has been developed. A quantitative assessment of internal dynamic load factor in an open gear transmission of МШЦ $5.5 \times 6.5$ ball mills has been carried out

Practical value. A method for determining the dynamic component of the load on a gear transmission containing a self-aligning drive gear has been developed.

Keywords: gear transmission, self-aligning gear, dynamic load, load factor

Introduction. Gear transmissions are the most commonly used drive elements in heavy duty machines. There is a tendency to increase the capacity of the drives to be used in tube mills, ball mills, and tube furnaces. Heavy duty gear transmissions with a shaft torque of about one hundred thousand kilonewtons per meter have been increasingly used. The reliability of these machines depends significantly on the reliability of the gear transmissions. The uneven distribution of the load along the width of the gear wheel is a feature of heavy duty low-speed gear transmissions, which leads to intense wear and tooth breakage [1]. Inaccuracy in the manufacture of the gear wheel, elastic deformation of the teeth, gear rim, shaft and its bearings, and the run-out of the support bearings lead to the occurrence of the tooth mesh misalignment [2]. As a result, the working surfaces of the meshed teeth are not parallel to each other and are positioned at a solid angle of tooth mesh misalignment $\gamma$ (Fig. 1). Poor contact of teeth in the operation leads to one-sided spalling and scuffing of the teeth, uneven wear along the length of the contact lines, and sound in gear transmissions [3].

Reshetov L. (1985) showed that due to the inevitability of tooth mesh misalignment along the contact line under a rigid installation of gears, there is an excessive connection resulting in uneven distribution of the load. The introduction of local mobility in the connection between the rim and the hub eliminates the excessive connection or reduces the effort required

(c) Vinogradov B. V., Fedin D. O., Samusia V. I., Kolosov D. L., 2021 to overcome it, which decreases the unevenness of the load distribution. O. Beresnev (1983) identified several groups of corresponding design solutions:

- wheels with increased compliance of teeth, disc or hub;

- gear wheels with overhead and built-in dampers;

- composite gear wheels with elastic mountings (including the use of polymer materials).

In heavy duty low-speed gear transmissions, where the transmitted moments reach hundreds of meganewtons per meter, the second and third groups of design solutions have not been widely used due to their lower strength and reliability. The principles underlying the first type design are being widely used in the gear transmissions of ball mills. The profile of the drum rim and the drive gear is always made non continuous in order to reduce the weight of the structure and increase the compliance. However, as shown by the research of the authors, this does not completely solve the problem. Excessive flexibility of the wheels leads to uneven load distribution in the wheel structure, which negatively affects its bearing capacity [4].

Another design concept of the first type group is a gear with a movable rim and spherical joint. The gear rim and the shaft are connected by splines $[5,6]$. The profile of the splines should be involute due to its higher bearing capacity, uniform load and lower stress concentration around the shaft as compared to straight-sided splines. The mobility of the gear rim is provided by an increase in lateral and radial clearances or a longitudinal change in the teeth working surfaces. With a constant angle of mesh misalignment, load balancing across the 
width of the gear rim can occur as a result of the teeth runningin. A feature of large-sized and heavy duty gear transmissions, such as gear wheels in a ball mill drive, is a variable component of the mesh misalignment angle. Therefore, the self-alignment process never occurs. Increased clearances lead to an increase in the dynamic load in the mesh. Consequently, the barrelshaped modification is more advisable, since with an uneven distribution of the load along the width of the gear rim, a torque will be created, which leads to the rolling of the teeth surfaces and turn of the gear in the direction of decreasing the mesh misalignment angle [5].

The need to use self-aligning gears is especially acute for ball mills, which are widely used for grinding various materials at concentrating mills in the mining industry, in the chemical industry for the production of cement, and at thermal power plants for grinding coal. Their world's share in technological processes related to the grinding of raw materials is more than $80 \%$. The process of material grinding is energy and metal consuming. Energy consumption in the grinding process is $7-10 \%$, and metal consumption $-2 \%$ of the total production in the world. In addition, the specific energy consumption for fine grinding is $20-60 \mathrm{kWh} / \mathrm{h}$. The world's industries are trying to reduce the cost of grinding through creating large-sized ball mills of high unit capacity. In the $60-80$ s of the last century, the engine power of the largest mills did not exceed 4000-5000 kW, while today, Metso Minerals (USA) manufactures mills with engine power exceeding $20000 \mathrm{~kW}$. Mills equipped with gear drives, containing open gear transmissions, require lower capital expenditures compared to other drive types. An increase in unit power for geared mills is constrained by the maximum power that an open gear transmission is able to transfer from the motor to the drum.

A peculiarity of the open gear transmissions in ball mills is that the gear rim is installed directly on the drum, and its diameter reaches 12 meters. The misalignment of the geometric axis of the gear rim and the axis of rotation of the drum reaches a significant value and leads to the face run-out of the rim. In ball mills from Novokramatorsk Machine Building Plant and in autogenous mills from Syzran Plant of Heavy Mechanical Engineering, the value of the face run-out of the gear rim reaches $2 \mathrm{~mm}$. The highest standard foreign mills feature the limiting value of the gear rim face run-out of $0.7 \mathrm{~mm}$. (Table 1). As a result, the tooth mesh misalignment angle consists of a constant component and a variable one. The constant component of the tooth mesh misalignment angle is prone to run-in, while the variable component is not, which leads to an uneven distribution of the load and, accordingly, to bending and contact stresses along the width of the gear rim. The occurrence of face run-out is one of the main factors limiting the amount of power transmitted through the rim to the drum by one drive gear.

The use of self-aligning gear transmissions in ball mills makes it possible to compensate for both the variable and constant components of the tooth mesh misalignment and, accordingly, transfer higher power from the motor to the drum. The problem of equipping the drives of domestic mills with self-aligning gear transmissions is even more relevant, since they have larger tolerances for errors in manufacturing and mounting.

Currently, drives with one self-aligning drive gear with a power of $7090 \mathrm{~kW}$ are in operation, and a drive with a power of $8209 \mathrm{~kW}$ transmitted to the drive shaft-gear has already been designed [7]. The next step in increasing the power transmitted to the drum is the power flow separation, when two or more drive gears work with one gear rim. For this purpose, two-motor drives and methods for uniform distribution of load between transmission lines have been developed. At present, ABB (Asea Brown Boveri Ltd.) manufactures double-motor drives equipped with frequency converters that allow smooth start-up and control of the drum rotation speed [8]. MAAG Gear AG (Switzerland) and FLENDER (Germany) have de-
Table 1

Basic mounting parameters and tolerances for open gear transmissions in Roxyle mills $30 \times 10$ and domestic mills

\begin{tabular}{|c|c|c|c|c|}
\hline 1 & $\begin{array}{l}\text { Drum } \\
\text { dimensions, mm }\end{array}$ & $9150 \times 3150$ & $9000 \times 3000$ & $5500 \times 6500$ \\
\hline 2 & $\begin{array}{l}\text { Engine power, } \\
\mathrm{kW}\end{array}$ & 3300 & 4000 & 4000 \\
\hline 3 & $\begin{array}{l}\text { Gear shaft } \\
\text { rotation } \\
\text { frequency, rpm. }\end{array}$ & 140 & 75 & 150 \\
\hline 4 & $\begin{array}{l}\text { Tooth module, } \\
\mathrm{mm}\end{array}$ & 34 & 28 & 25 \\
\hline 5 & $\begin{array}{l}\text { Number of teeth: } \\
\text { - gears } \\
\text { - rim }\end{array}$ & $\begin{array}{c}23 \\
304\end{array}$ & $\begin{array}{c}42 \\
284\end{array}$ & $\begin{array}{c}46(25) \\
252\end{array}$ \\
\hline 6 & Tooth width, mm & 775 & 1000 & 1000 \\
\hline 7 & $\begin{array}{l}\text { Hardness of the } \\
\text { teeth working } \\
\text { surfaces, HB: } \\
\text { - gears } \\
\text { - rim }\end{array}$ & $\begin{array}{c}550 \\
265-280\end{array}$ & $\begin{array}{l}260-300 \\
180-200\end{array}$ & $\begin{array}{l}260-300 \\
180-200\end{array}$ \\
\hline 8 & $\begin{array}{l}\text { Non-horizontal } \\
\text { positions of plate } \\
\text { foundations, mm }\end{array}$ & 0.1 & 0.1 & 0.1 \\
\hline 9 & $\begin{array}{l}\text { Clearance } \\
\text { between the faces } \\
\text { of the gear rim } \\
\text { sectors, } \mathrm{mm}\end{array}$ & 0.04 & 0.12 & 0.05 \\
\hline 10 & $\begin{array}{l}\text { Maximum radial } \\
\text { run-out of the } \\
\text { gear rim, } \mathrm{mm}\end{array}$ & 0.7 & 2.0 & 2.0 \\
\hline 11 & $\begin{array}{l}\text { Maximum face } \\
\text { run-out of the } \\
\text { gear rim, } \mathrm{mm}\end{array}$ & 0.7 & 2.0 & 2.0 \\
\hline 12 & $\begin{array}{l}\text { Maximum } \\
\text { tolerance for } \\
\text { radial clearance } \\
\text { in the open gear } \\
\text { transmission } \\
\text { mesh, mm }\end{array}$ & 1.4 & 2.0 & 4.35 \\
\hline 13 & $\begin{array}{l}\text { Open gear } \\
\text { transmission } \\
\text { contact patch, \% }\end{array}$ & 75 & 60 & 60 \\
\hline
\end{tabular}

veloped lateral gear drives, which make it possible to transmit torque through the gear rim to the drum by two drive gears [7].

Despite the increasingly widespread use of self-aligning gears, there is currently no theoretical basis for determining the degree of load balancing along the width of the gear rim or the effect of an additional degree of freedom on the dynamics of the gearing. This does not allow assessing the area of effective application of self-aligning gears and complicates the calculation of their strength. A few experiments on a scale model of the self-aligning gear transmission indicate the influence of the mesh misalignment angle on the dynamic characteristics of the gear transmission (S. Yang, L., 2010). Studies have shown that the alignment process is accompanied by the occurrence of torque fluctuations in the drive shaft. There is a direct relationship between the mesh misalignment angle and the amplitude of the torque oscillations.

Therefore, it is of considerable interest to study the influence of the unsteady gear movement on the dynamic loads in the gear transmission during the period of compensation of the mesh misalignment angle.

The purpose of the work is to develop a mathematical model of a self-aligning gear transmission, which would take 
into account the occurrence of dynamic loads on the gear transmission due to the process of the gear alignment.

Mathematical model. Let us consider the movement of a self-aligning gear, whose schematic diagram is shown in Fig. 1. The movement of the movable rim of the gear on the spherical bearing surface of the gear shaft, in the most general case, is a rotation around the fixed point $O_{h}$ lying in the geometric center of the spherical bearing surface. In this case, all the three axes of rotation continuously change their position in space. The deformation of the shaft and gear can be obviously neglected during the motion until the moment of engaging into mesh. Then the equations of the gear motion can be represented as

$$
\begin{aligned}
& N_{x}=I_{1} \dot{\omega}_{x}+\left(I_{3}-I_{2}\right) \omega_{y} \omega_{z} ; \\
& N_{y}=I_{2} \dot{\omega}_{y}+\left(I_{1}-I_{3}\right) \omega_{x} \omega_{z} ; \\
& N_{z}=I_{3} \dot{\omega}_{z}+\left(I_{2}-I_{1}\right) \omega_{x} \omega_{y},
\end{aligned}
$$

where $N_{x}, N_{y}, N_{z}$ are components of the external moment relative to the main axes $x, y, z ; \omega_{x}, \omega_{y}, \omega_{z}$ are components of the angular velocity relative to the main axes; $I_{1}, I_{2}, I_{3}$ are the main moments of the body inertia.

This system of equations can only be solved by numerical methods. The lack of an exact solution and uncertainty in the boundary conditions reduces the value of this approach for engineering practice. A numerical study on the equations will make it possible to draw some qualitative conclusions about the self-alignment process. At the same time, internal dynamic loads are known to be largely caused by tooth strikes. The speed of the relative movement of the gear relative to the driven wheel determines the amplitude of the dynamic component of the moment in the mesh. This approach allows making a number of assumptions that reduce the system of equations (1) to an ordinary differential equation, with further obtaining an exact solution.

Let us consider the movement of the gear relative to the driven wheel in the presence of a mesh misalignment.

We make the following assumptions:

- elastic deformations can be neglected due to their smallness;

- the interaction of the gear teeth and the driven wheel occurs during the period of single-pair mesh;

- the relative speed of the gear wheels at the initial moment of time is equal to zero;

- the mesh misalignment angle is a small, acute, flat angle in the meshing plane;

- the bearing surface of the moving part of the gear is spherical and unchangeable;

- the force interaction of the moving part of the gear and the bearing surface occurs through the contact area $S$;

- the dimensions of the area $S$ are comparable to the dimensions of the bearing surface;

- the location of the area $S$, its size and the distributed force at each moment of time is determined by external and inertial forces acting on the gear.

In relative motion, the driven wheel can be represented as a stationary one, and the movable part of the gear as making spatial motion under the action of the drive torque $M_{d v}$ applied to it (Fig. 1). The spherical bearing surface of the movable gear rim allows it to only perform a rotational movement relative to the geometric center of the gear. Then the relative movement of the gear rim can be considered as rotation about the fixed axis $O A$ passing through the geometric centre of the gear $O$ and the contact point of the gear teeth and driven wheel $A$. The smallness of the mesh misalignment angle allows us to consider the axis $O A$ stationary.

The rotation of the gear occurs under the action of a driving moment. The internal meshing is made as an involute spline connection, where the splines of the gear shaft have a barrel-shaped longitudinal modification that allows the gear rim to roll around them. In the absence of misalignment, the

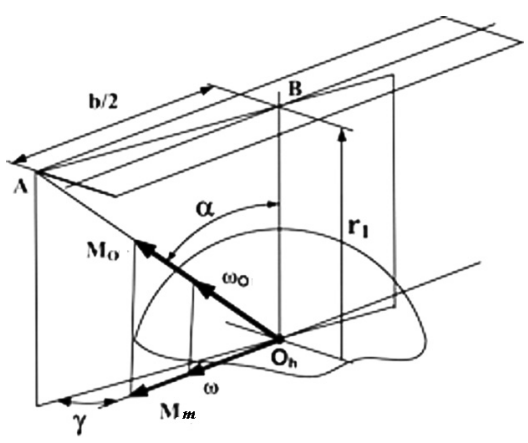

Fig. 1. Calculation schematic diagram of the relative motion of the gear rim:

$A$ - point of the teeth contact; $B$ - the geometric centre of the gear tooth section by the plane of action; $O_{h}$ - the centre of the gear rotation; $O A$ - the axis of the gear rim rotation; $b$ - tooth width; $M_{m}$ vector of driving moment; $M_{o}$ - the projection of the $M_{m}$ vector onto the axis of rotation; $r_{1}$ - the radius of the pitch circle; $\alpha$ - the angle between the axis of the rim rotation and $O B$ axis; $\gamma$ - mesh misalignment angle; $\omega$ - vector of the angular speed of rotation of the drive shaft; $\omega_{O}$ is the projection of the vector $\omega$ onto the OA axis

vector of the angular velocity of the gear $\omega$ and the vector $M_{d v}$ coincide in direction and are directed in a plane perpendicular to the longitudinal plane of the gear wheels; they pass through the geometric center of the gear. In the presence of an uncompensated misalignment angle $\gamma$, the vector of the relative angular velocity $\omega$ deviates towards the axis $O A$, the projection of the moment vector onto which is

$$
M_{O o}=M_{m} \cos (\gamma) \sin (\alpha) \approx \sin (\alpha) .
$$

Part of the transmitted energy is lost to overcome the frictional forces arising from the force interaction of the gear rim and spherical bearing surface. The frictional moment can be determined according to the Coulomb law by the formula (Ilyin V.A., 1985)

$$
M_{f r}=f_{\tau} \cdot \rho \cdot \iint_{s} p(M) d S,
$$

where $f_{\tau}$ is the sliding friction coefficient $\left(f_{\tau}=\right.$ const $) ; \rho$ is the radius of curvature of the joint surface $(\rho=$ const $=R) ; p(M)$ is the law of normal pressure distributions over the joint surface (Fig. 2).

However, due to the inevitable deviation of the contact surface from the spherical one, the contact will occur over a small area, so the force interaction can be reduced to a point interaction (Fig. 2, b).

Then expression (3) is transformed to the form

$$
M_{f r}=f \cdot \rho \cdot R_{n}
$$

During the operation of the gearing, the process of appearing and closing the mesh misalignment angle occurs simultaneously. The mesh misalignment angle will be compensated by elastic deformations and relative movement of the moving part of the gear.

In the case when the process of alignment of the resulting unevenness is ahead, the opening of the mesh misalignment angle does not occur.

The face run-out of the gear rim leads to the fact that the mesh misalignment angle will change from a minimum to a maximum value. A pair of teeth will engage with a maximum tooth mesh misalignment angle, for example, in a mill МШЦ $5.5 \times 6.5$, every 126 engagements (Vinogradov B. V., 2015).

It can be assumed that with a large radial run-out of the gear rim, wear of the teeth, single-pair engagement and mating of a "dangerous" pair of teeth with the largest tooth mesh misalignment significantly exceeding the elastic deformations aimed at compensating for it, a partial opening of the mesh misalignment angle will occur. Let us consider the influence of 

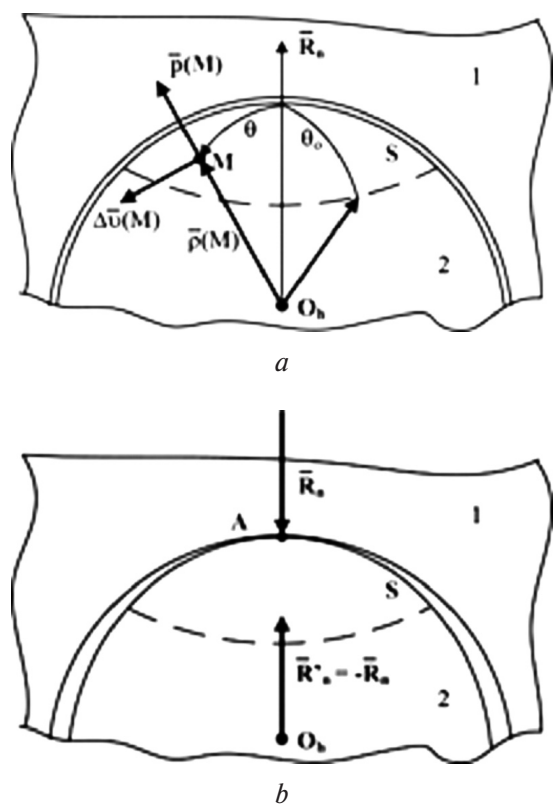

Fig. 2. Force interaction between the gear rim and the spherical bearing surface:

1 - gear rim; 2 - spherical bearing surface; $O_{h}$ - the center of rotation of the gear; $M$ is the point on the contact area; $S$ - contact area; $\bar{\rho}(M)-$ radius of curvature of the contact area at point $M$; $\Delta \bar{v}(M)$ is the vector of the velocity increment at point $M ; \bar{p}(M)$ is the normal pressure vector on the contact area at point $M$

the uncompensated mesh misalignment angle on the dynamic loads in the gearing.

The equivalent dynamic scheme of the ball mill drive in steady-state operation is shown in Fig. 3, $a$, where $I_{1}, I_{2}, I_{3}$ are the reduced moments of inertia of the motor rotor, gear and drum; $c_{0}, c_{1}, c_{2}$ are torsional stiffness of the electromagnetic field of the synchronous motor, mechanical transmission and gear transmission, respectively. Since the reduced moments of inertia of the motor rotor and drum $I_{1}$ and $I_{2}$ are several orders of magnitude greater than the moment of inertia of the gear, then in solving the problems of the drive dynamics in the period when there is no connection between the gear and the drum, the mass of the motor rotor and drum can be consid-
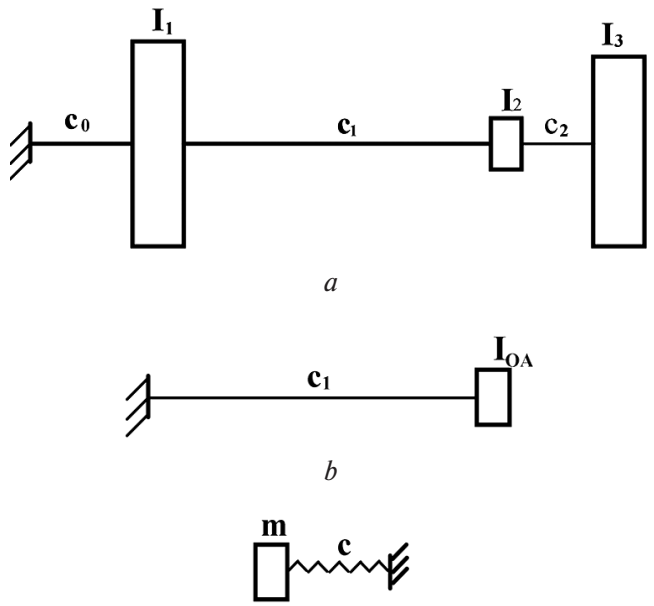

Fig. 3. Equivalent dynamic schemes:

$a$ - ball mill drive; $b$ - the moving part of the drive gear in the absence of connection with the drum; $c$ - gear transmission. $I_{1}, I_{2}$, $\mathrm{I}_{3}$ - reduced moments of inertia of the motor rotor, gear, drum and moving part of the gear; $c_{0}, c_{1}, c_{2}$-torsional stiffness of the electromagnetic field of the synchronous motor, mechanical transmission, and gear transmission; $s, m$ - linear stiffness and mass of the gear ered infinitely large. The equivalent dynamic scheme for this case is shown in Fig. 3, $b$. Since the stiffness of the mechanical transmission of the drive is several orders of magnitude less than the stiffness of the gear transmission $\left(c_{1} \ll c_{2}\right)$, then in solving the problems of the gearing dynamics, in addition, the stiffness $c_{1}$ can be taken as infinitesimal. Then the equivalent dynamic gear scheme takes the form shown in Fig. 3, c.

At the initial moment, before the formation of the mesh misalignment angle, in the gearing, the mechanical transmission of the drive is loaded with a static torque (Fig. 3, b). Under the action of this elastic moment, the moving part of the gear starts to make angular movements aimed at reducing the mesh misalignment angle $\gamma$. The equations of motion during this period, given that, will have the form

$$
I_{O A} \ddot{\gamma}_{1}+c_{1}=-M_{f r},
$$

where are moments of inertia of the moving part of the gear relative to the axis $O A ; c_{1}$ is torsional stiffness of the mechanical drive system.

It is known that the moment of inertia of a rigid body about an axis that does not coincide with the principal axes of inertia is

$$
I_{O A}=I_{x} \cos ^{2} \beta+I_{y} \cos ^{2} \theta_{y}+I_{z} \cos ^{2} \theta_{z},
$$

where $\beta, \theta_{y}, \theta_{z}$ are the angles between the axis $O A$ and the main axes of inertia of the body (Fig. 4). Due to the smallness of the mesh misalignment angle, the axis $O A$ can be considered to be in the $x O y$ plane. Then $\theta_{y}=\alpha ; \theta_{z}=90^{\circ}$, and the angle $\alpha$ is fully determined by the dimensions of the gear and is obtained from the expression

$$
\alpha=\operatorname{arctg}\left(\frac{b}{2 R_{1}}\right),
$$

where $R_{1}, b$ are pitch radius and gear width, respectively.

It is quite obvious that before the teeth engage into mesh, the moments of inertia of the gear are the moments of inertia of its rim and they can be found as the moments of inertia of an equivalent hollow cylinder with an inner radius $r_{1}$, an outer radius $R_{1}$ and a length $b$ according to the formulas

$$
\begin{gathered}
I_{x}=\frac{m_{1}}{2}\left(r_{1}^{2}+R_{1}^{2}\right) ; \\
I_{y}=I_{z}=\frac{m}{12}\left(3\left(r_{1}^{2}+R_{1}^{2}\right)+b^{2}\right) .
\end{gathered}
$$

The mass of the gear rim is $5231 \mathrm{~kg}$, and the calculated values of the main moments of inertia are $I_{x}=1131.4 \mathrm{~kg} \cdot \mathrm{m}^{2}$; $I_{y}=I_{z}=908.9 \mathrm{~kg} \cdot \mathrm{m}^{2}$. For the gear under consideration, the angle $b=0.7$. Then, using formulas (5), we can determine the moment of inertia relative to the axis of rotation $I_{O A}=$ $=980.5 \mathrm{~kg} \cdot \mathrm{m}^{2}$.

Solution of equation (4) with initial conditions

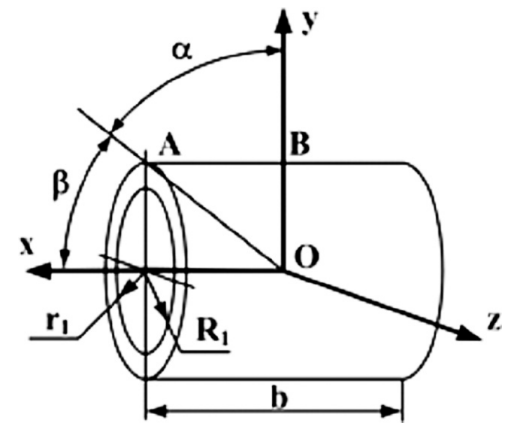

Fig. 4. Axes of inertia of the gear:

$b$ - gear width; $r_{1}$ - inner radius of the moving part of the gear; $R_{1}$ - outer radius of the moving part of the gear; $x, y, z-$ main axes of inertia 


$$
t=0 ; \quad \gamma=-\frac{\left(M_{s t}-M_{f r}\right) \sin (\alpha)}{c_{1}} ; \quad \dot{\gamma}=0,
$$

takes the form

$$
\begin{gathered}
w_{O A 1}=-\frac{\left(M_{s t}-M_{f r}\right) \sin (\alpha)}{c_{1}} \cos \left(\sqrt{\frac{c_{1}}{I_{O A}}} t\right) \\
w_{O A 1}=\frac{\left(M_{s t}-M_{f r}\right) \sin (\alpha)}{c_{1}} \sqrt{\frac{c_{1}}{I_{O A}}} \sin \left(\sqrt{\frac{c_{1}}{I_{O A}}} t\right) .
\end{gathered}
$$

When counting from the initial position of the mass $I_{1}$, the movement in the direction of decreasing the mesh misalignment angle is described by the equation

$$
\begin{aligned}
& \gamma_{1}=\frac{\left(M_{s t}-M_{f r}\right) \sin (\alpha)}{c_{1}}\left(1-\cos \sqrt{\frac{c_{1}}{I_{O A}}} t\right) . \\
& \begin{array}{c}
w_{0}=\frac{M_{s t} \sin (\alpha)}{c_{1}} \sqrt{\frac{c_{1}}{I_{\hat{I} \dot{A}}}} \times \\
\times \sqrt{\frac{c_{1} \gamma_{0}}{\left(M_{s t}-M_{f r}\right) \sin (\alpha)}\left[2-\frac{c_{1} \gamma_{0}}{\left(M_{s t}-M_{f r}\right) \sin (\alpha)}\right]} .
\end{array}
\end{aligned}
$$$$
\sin \left(\sqrt{\frac{c_{1}}{I_{\hat{I} A}}} t_{1}\right)=\sqrt{\frac{c_{1} \gamma_{0}}{M_{s t} \sin \left[\alpha_{1}-\frac{c_{1} \gamma_{0}}{\left(M_{s t}-M_{f r}\right) \sin (\alpha)}\right]}\left[2-\frac{c_{1} \gamma_{0}}{\left(M_{s t}-M_{f r}\right) \sin (\alpha)}\right]} .
$$

or from the expression the expressions

The value of the angle at each moment $t$ is determined

$$
\gamma_{2}=\gamma_{0}-\frac{\left(M_{s t}-M_{f r}\right) \sin (\alpha)}{c_{1}}\left(1-\cos \sqrt{\frac{c_{1}}{I_{O A}}} t\right) .
$$

When $\gamma_{2}=0$ or $\gamma_{1}=\gamma_{0}$, time $t_{1}$ of decreasing the mesh misalignment angle $\gamma_{0}$ according to (8) can be determined from

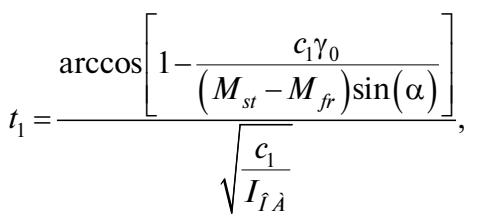
angular velocity of the moving part of the gear at the moment

At the moment of the gear teeth meshing with the teeth of the rim, the linear speeds will be distributed along the length of the gear rim according to the law

$$
v=v=0.5 w_{0} h,
$$

where $h$ is the radius of rotation.

The maximum speed corresponds to the point whose radius of rotation is

$$
h_{\max }=\frac{b_{w} d_{1}}{\sqrt{b_{w}^{2}+d_{1}^{2}}}
$$

where $d_{1}$ is the diameter of the gear.

Substitute the value $w_{0}$ from (11) in (12) and $h_{\max }$ from (13) to determine the average rate of gearing deformation at the initial moment

$$
v_{0}=0.5 w_{0} \frac{b_{w} d_{1}}{\sqrt{b_{w}^{2}+d_{1}^{2}}} .
$$

In accordance with the equivalent dynamic scheme of the gear transmission (Fig. 3,c), the differential equation of motion has the form

$$
m \ddot{x}+c x=F_{s t} .
$$

At the initial moment, the gear train is loaded with torque

$$
M_{0}=M_{s t}-c_{110},
$$

which corresponds to the force

$$
F_{0}=F_{s t}-\frac{2}{d} c_{1} \frac{\gamma_{0}}{\sin (\alpha)},
$$

where $\varphi_{10}$ is angular deformation of the mechanical transmission during the period of decreasing the mesh misalignment angle $\gamma_{0} ; F s t$ is the static component of the force.

Having solved equation (15) with the initial conditions

$$
t=0 ; \quad x_{0}=\frac{F_{s t}}{c}-\frac{c_{1}}{c} \frac{\gamma_{0}}{\sin (\alpha)} ; \quad \dot{x}_{0}=v_{0},
$$

we define the maximum dynamic force acting in the gearing

$$
F_{\text {vmax }}=\sqrt{\left(-\frac{c_{1} \gamma_{0}}{\sin (\alpha)}\right)^{2}+m c v_{0}^{2}} .
$$

The dynamic load was estimated by the value of the dynamic factor, which is the ratio of the maximum force in the gear transmission to its dynamic component

$$
k_{v}=\frac{F_{s t}+F_{v \max }}{F_{s t}}=1+\frac{F_{v \max }}{F_{s t}} .
$$

Calculation results. Fig. 5 shows the dependence of the dynamic factor $k_{v}$ on the value of the uncompensated mesh misalignment angle $\gamma_{0}$ for the self-aligning gear of the open gear transmission of the МШЦ $5.5 \times 6.5$ mill with the following initial data: $I_{O A}=980.5 \mathrm{kgm}^{2} ; m=7500 \mathrm{~kg} ; c_{1}=5 \cdot 10^{7} \mathrm{Nm} ; c=$ $=8 \cdot 10^{9} \mathrm{~N} / \mathrm{m} ; M_{s t}=471 \cdot 10^{3} \mathrm{Nm} ; F_{s t}=819 \cdot 10^{3} \mathrm{~N} ; \alpha=0.663 ;$ $d=1.15 \mathrm{~m} ; M_{f r}=0$.

The use of self-aligning gears will be only effective in cases when the self-alignment time is much less than the time for re-meshing the gear transmission.

In the case under consideration, the gear-meshing frequency $f$ of the open transmission in the ball mill and the period of re-meshing the teeth $T$ are equal to

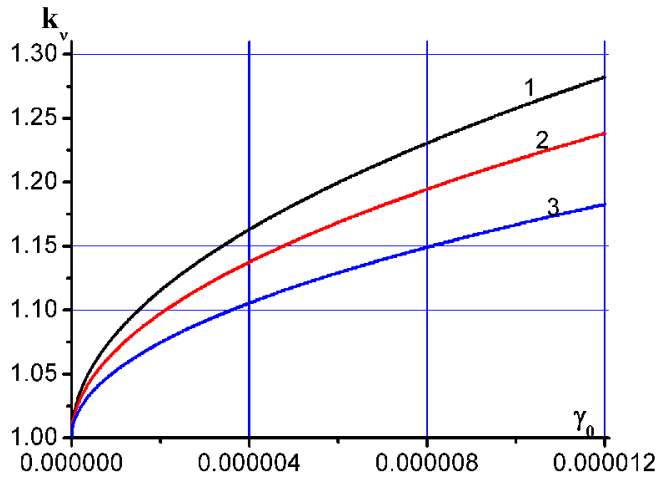

Fig. 5. Dependence of the dynamic factor $k_{v}$ on the mesh misalignment angle $\gamma_{0}$ and gear tooth width $b_{w}$ : $1-b_{w}=0.9 ; 2-b_{w}=0.7 ; 3-b_{w}=0.5$ 


$$
\begin{gathered}
f_{c}=\frac{n z_{1}}{60}=\frac{75 \cdot 46}{60}=57.5 ; \\
T=\frac{1}{f_{c ̧}}=0.018 .
\end{gathered}
$$

The time of the mesh misalignment angle decreasing at $\gamma_{0}=1.2 \cdot 10^{-5}$ according to formula (8) is $t_{1}=0.000285 \mathrm{~s}$. Since the time of self-alignment of the gear is several orders of magnitude less than the time of re-meshing of the teeth $\left(t_{1} \ll T\right)$, then, given the above inertial parameters of the gear and loads on the gear transmission, the mesh misalignment angle will be compensated by the relative movement of the moving part of the gear during each period of the teeth meshing. Analysis of the calculated data shows that the use of self-aligning gears can lead to additional dynamic loads in the gearing, which has been confirmed experimentally (S. Yang, L., 2010).

The dominant effect on the dynamic loads is exerted by the mass $m$ of the gear, the stiffness of the gearing $m_{c}$ and the contact rate $v_{0}$. Other parameters being unchanged, the initial speed $v_{0}$ and dynamic factor $k_{v}$ are determined by the mesh misalignment angle $\gamma_{0}$ and the width of the $\operatorname{rim} b_{w}$.

In addition, the use of self-aligning gears does not completely eliminate the uneven distribution of the load along the width of the gear rim. At large values of the tooth width, typical for open gear transmissions in ball mills, the rigidity of the teeth along the width changes significantly, which causes uneven distribution of the load even in the absence of a mesh misalignment angle between the teeth. The calculations carried out by the authors by the finite element method show that for the gear under consideration, with full compensation of the mesh misalignment angle, the coefficient that takes into account the uneven distribution of the load along the width of the gear $\operatorname{rim}$ is $K=1.2$.

Thus, the use of a self-aligning gear with a tooth mesh misalignment angle of $0.3 \cdot 10^{-3} \mathrm{rad}$ allows reducing the factor of uneven load distribution $K_{F \beta}$ from 2.7 to 1.2.

Additional loads arising in the gear transmission due to the uneven distribution of the load $K_{F}$ and the internal dynamic load $k v$ are formally taken into account by the load factor when calculating the strength [9].

$$
k=k_{F \beta} k,
$$

where $K_{v}$ is the dynamic factor; $K_{F \beta}$ is face load factor for tooth root stress.

It is obvious that the use of a self-aligning gear will be effective in the event that $k v 1.2<2.7$. For example, the use of a self-aligning gear in central discharge ball mills МШЦ $5.5 \times 6.5$, with all other parameters being unchanged and $k_{v}=$ $=1.3$, allows the load factor to be reduced from 2.7 to 1.3 $1.2 \approx 1.6$. Consequently, the use of a self-aligning gear, in this case, will reduce the load on the gear transmission by 1.7 times.

\section{Conclusions.}

1. An approximate method has been developed for calculating the gear meshing dynamics in an open transmission of a drum mill that contains a self-aligning drive gear for the case when the tooth mesh misalignment angle significantly exceeds the elastic deformations working in its compensation.

2. It has been shown that the use of a self-aligning gear can lead to an increase in dynamic loads on the gear transmission, and the dynamic loads increase with an increase in the tooth width and uncompensated mesh misalignment angle.

3. Due to elastic deformations of the teeth, the use of a self-aligning gear does not allow for an absolutely uniform distribution of the load along the width of the tooth, on the one hand. On the other hand, it leads to an increase in the internal dynamic load. Therefore, the use of self-aligning gears will be only effective in the case when this results in a decrease in the load factor, equal to $k=k_{F \beta} k_{v}$.
References.

1. Rajagopal, M., Kumar, N.S., \& Rao, P. N. (2016). Minimizing Tooth Mesh Misalignment in Heavy Duty Tractor Transmission. SAE Technical Paper, 2016-01-8069. https:// doi.org/10.4271/2016-01-8069.

2. Jiang, H., Shao, Y., \& Mechefske, C. K. (2015). The influence of mesh misalignment on the dynamic characteristics of helical gears including sliding friction. Journal of Mechanical Science and Technology, 29, 4563-4573. https://doi. org/10.1007/s12206-015-1001-5.

3. Parey, A., Jain, N., \& Koria, S. (2014). Failure analysis of air cooled condenser gearbox. Case Studies in Engineering Failure Analysis, 2, 150-156. https://doi.org/10.1016/j.csefa.2014.08.003.

4. Vinogradov, B. V., \& Fedin, D. O. (2016). The stress state of heavy loaded open gearing with incomplete teeth contact. Naukovyi Visnyk Natsionalnoho Hirnychoho Universytetu, (3), 35-40.

5. Rotatable drum (n.d.). Retrieved from https://patents. google.com/patent/US4911554A/en?q= pinion\&assignee $=\mathrm{kr}$ upp + polysius\&oq $=\mathrm{krupp}+$ polysius + pinion .

6. Drive for a rotary drum (n.d.). Retrieved from https://patents.google.com/patent/US20120312113A1/en?q=pinion\&as signee $=\mathrm{krupp}+$ polysius $\&$ oq $=\mathrm{krupp}+$ polysius + pinion .

7. Fabrice Lessard, Michel Pasquier, Fabrice Wavelet, Brady McNaughton, \& Frank J. Tozlu (n.d.). QdX ${ }^{T M}$, A Mechanical Drive Train Solution for High-Powered Grinding Mills (CMD, Ferry-Capitain and Metso). Retrieved from https://ru.scribd. com/document/296770415/42-Frank-Tozlu-QdX4-A-Mechanical-Drive-Train-Solution-for-High-Powered-Grinding-Mills.

8. Van de Vijfeijken, M., Filidore, A., Walbert, M., \& Marks, A. (2012). Copper mountain: overview on the grinding mills and their dual pinion mill drives. SAG Conference, Vancouver $B C-$ September, (pp. 1-20). Retrieved from https://library.e.abb. com/public/d43c675f94ad66abc125793d0056168e/COPPER\%20MOUNTAIN\%20-\%20OVERVIEW\%20ON\%20 THE \% 20 GR IN D ING \% 20 M I LL S \% 20 A N D \% 20 THEIR\%20DUAL\%20PINION\%20MILL\%20DRIVES.pdf. 9. ISO 6336-1:2006. Calculation of load capacity of spur and helical gears - Part 1: Basic principles, introduction and general influence factors. Geneva: International Organization for Standardization (n.d.). Retrieved from https://www.iso.org/standard/36327.html.

\section{Динамічні навантаження в самовстановлювальних зубчастих передачах високонавантажених машин}

\author{
Б. В. Виноградов ${ }^{1}$, Д. О. Федін ${ }^{1}$, В. І. Самуся ${ }^{2}$, \\ Д.Л. Колосов ${ }^{2}$
}

1 - Державний вищий навчальний заклад «Український державний хіміко-технологічний університет», м. Дніпро, Україна, e-mail: borvvin@gmail.com

2 - Національний технічний університет «Дніпровська політехніка», м. Дніпро, Україна

Мета. Створення математичної моделі важконавантаженої зубчастої передачі із самовстановлювальною приводною шестернею, а також визначення динамічного навантаження на зубчасту передачу внаслідок процесу встановлення шестерні.

Методика. Розрахункова схема й рівняння відносного руху самовстановлювальної приводної шестерні складені за допомогою методів динаміки твердого тіла. Аналітичні вирази для визначення часу самовстановлення шестерні, швидкості при зіткненні й коефіцієнту динамічного навантаження отримані шляхом інтегрування звичайного диференціального рівняння. Для визначен- 
ня коефіцієнта динаміки використані методи лінійної теорії коливань.

Результати. Досліджено сучасний стан питання щодо конструкції, а також математичного моделювання самовстановлювальної шестерні. Із використанням методів динаміки твердого тіла складено рівняння відносного руху рухомої частини шестерні. Показано, що за допомогою висунутих гіпотез рух шестерні можна звести до обертання навколо миттєвої осі. Досліджено вплив геометричних і динамічних параметрів приводу барабанного млина на динамічні завантаження у відкритої зубчастої передачі. Отримані залежності швидкості встановлення шестерні від кута перекосу зубчастої передачі та інерційних параметрів шестерні. За допомогою отриманих залежностей обчислені час і швидкість установлення шестерні відкритої зубчастої передачі барабанного млина МШЦ 5,5 × 6,5. Показано, що в реальному діапазоні значень кута перекосу й параметрів шестерні час ії встановлення на кілька порядків менше часу перезачеплення зубів. За наявності змінної складової кута перекосу шестерня буде постійно здійснювати відносний рух з ударами, i, у залежності від поточного значення кута перекосу, динамічне навантаження на зубчасту передачу може бути значним. Показано, що при встановленні ефективності застосування самовстановлювальної шестерні необхідно враховувати можливе збільшення динамічних навантажень. Обчислено коефіцієнт динаміки та коефіцієнт навантаження для номінального значення кута перекосу відкритої зубчастої передачі барабанного млина МШЦ 5,5 × 6,5.

Наукова новизна. Розроблена математична модель динаміки самовстановлювальної зубчастої передачі приводу високо навантажених машин. Проведена кількісна оцінка коефіцієнта внутрішнього динамічного навантаження відкритої зубчастої передачі барабанного млина МШЦ 5,5 × 6,5.

Практична значимість. Створена методика визначення динамічної складової навантаження на зубчасту передачу зі самовстановлювальною приводною шестернею.

Ключові слова: зубчаста передача, самовстановлювальна шестерня, динамічне навантаження, коефіцієнт навантаження

\section{Динамические нагрузки в самоустанавливающихся зубчатых передачах высоконагруженных машин}

\section{Б. В. Виноградов ${ }^{1}$, Д. А. Федин ${ }^{1}$, В. И. Самуся², Д.Л. Колосов ${ }^{2}$}

1 - Государственное высшее учебное заведение «Украинский государственный химико-технологический университет», г. Днепр, Украина, e-mail: borvvin@gmail.com 2 - Национальный технический университет «Днепровская политехника», г. Днепр, Украина

Цель. Создание математической модели тяжелонагруженной зубчатой передачи с самоустанавливающейся приводной шестерней, а также определение динамиче- ской нагрузки на зубчатую передачу вследствие процесса установления шестерни.

Методика. Расчетная схема и уравнения относительного движения самоустанавливающейся приводной шестерни составлены с помощью методов динамики твердого тела. Аналитические выражения для времени самоустановления шестерни, скорости соударения при установлении и коэффициента динамической нагрузки получены путем интегрирования обыкновенного дифференциального уравнения. Для определения коэффициента динамики использованы методы линейной теории колебаний.

Результаты. Исследовано современное состояние вопроса касательно конструкции, а также математического моделирования самоустанавливающейся шестерни. С использованием методов динамики твердого тела составлено уравнение относительного движения подвижной части шестерни. Показано, что с помощью выдвинутых гипотез движение шестерни можно свести к вращению относительно мгновенной оси. Исследовано влияние геометрических и динамических параметров привода барабанной мельницы на динамические загрузки в открытой зубчатой передаче. Получены зависимости скорости установления шестерни в зависимости от угла перекоса зубчатой передачи и инерционных параметров шестерни. С помощью полученных зависимостей вычислены время и скорость установления шестерни открытой зубчатой передачи барабанной мельницы МШЦ 5,5 × 6,5. Показано, что в реальном диапазоне значений угла перекоса и параметров шестерни время её установления на несколько порядков меньше времени перезацепления зубьев. При наличии переменной составляющей угла перекоса шестерня будет постоянно совершать относительное движение с ударами, и, в зависимости от текущего значения угла перекоса, динамическая нагрузка на зубчатую передачу может быть значительна. Показано, что при установлении эффективности применения самоустанавливающихся шестерен необходимо учитывать возможное увеличение динамических нагрузок. Вычислен коэффициент динамики и коэффициент нагрузки для номинального значения угла перекоса открытой зубчатой передачи барабанной мельницы МШЦ 5,5 × 6,5

Научная новизна. Разработана математическая модель динамики самоустанавливающейся зубчатой передачи привода высоконагруженных машин. Проведена количественная оценка коэффициента внутренней динамической нагрузки открытой зубчатой передачи барабанной мельницы МШЦ 5,5 × 6,5.

Практическая значимость. Создана методика определения динамической составляющей нагрузки на зубчатую передачу, содержащую самоустанавливающуюся приводную шестерню.

Ключевые слова: зубчатая передача, самоустанавливающаяся шестерня, динамическая нагрузка, коэффициент нагрузки

Recommended for publication by V.V.Protsiv, Doctor of Technical Sciences. The manuscript was submitted 07.04.20. 